\title{
FATHOMING THE FUTURE OF ARTIFICIALLY INTELLIGENT ROBOTS
}

\author{
BRIAN E. WHITE \\ Complexity Are Us $\leftarrow$ Systems Engineering Strategies, USA.
}

\begin{abstract}
The world abounds with massive efforts to further develop artificial intelligence, mostly with hopes of achieving greater benefits to humankind. Not surprisingly, there is relatively little concern about the dangers associated with the, as yet hypothetical, eventual situation where robots might possess humanlike capabilities of cognition, emotional experience, learning, etc. The following five propositions will be examined:
\end{abstract}

1. Could the most advanced robots 'evolve' to truly human-being levels of achievement within a foreseeable time frame?

2. Will robots ultimately take over all the jobs, including the making of robots, with relatively few human owners of robots (and most everything else) in charge?

3. Will humans live much longer and essentially turn into pseudo-robots through receiving more replacement body parts, even involving portions of the brain?

4. What are the possibilities of being psychologically manipulated by authoritarians using Big Data in knowing what citizens care about and how people think?

5. Will humans keep losing not only manual jobs but also knowledge positions with increasing robotic capabilities and the attractions of robotic replacements?

The conclusive answers: a 'no' to Proposition 1; a 'maybe' to 2; possible 'yeses' to 3 and 4; and a definite 'yes' to 5; will be explained.

This subject quite obviously overlaps some combination of at least three of our conference themes, viz., Complex Systems Engineering, Global Issues and Social Systems. The paper's focus will be on framing the above-described topics in a matrix with two dimensions: holistic thinking perspectives (big picture, operational, functional, structural, generic, continuum, temporal, quantitative and scientific) and journalist questions (who, what, where, when, why and how). Several of the more interesting topics from this milieu will be elaborated upon to stimulate further thought, discussion, and research efforts.

Keywords: artificial intelligence, behaviors, complex systems, complex systems engineering, families of robots, global issues, humans, jobs, robots, social systems.

\section{INTRODUCTION}

The topics of this paper's title and abstract are emergent, rather popular, quite controversial, far-ranging, and very challenging. The author here attempts to treat some of this and the supporting literature in a meaningful fashion to not only express his point of view but also encourage others to weigh in with their perspectives and argue their similar or contrary viewpoints, hopefully with additional research.

The remainder of this introduction includes some relevant acronyms/definitions, the discussion framing, and a natural evolution of robotic phases. Section 2 sets up considerations of the propositions (treated in Section 3), and this author's conclusions are summarized in Section 4. In addition to the referenced citations, this author's comments inserted within quotations are demarcated by brackets, i.e., [...]. 


\subsection{Acronyms and definitions}

The following terms, listed in alphabetical order, will be utilized in the paper.

- Agency: set of ('outside' oriented) mental abilities of thinking and doing including communication, logic, memory, morality, planning, recognition, and self-control [1, p. 11]

- AGI: artificial general intelligence; human-level AI [2, pp. 8, 17]

- AI: artificial intelligence

- ASI: artificial super intelligence; intelligence greater than humans [2, p. 8]

- Automatic: working by itself with little or no direct human control

- Automation: the use of largely automatic equipment in a system of manufacturing or other production process [3]

- Experience: set of ('inside' oriented) mental capacities of sensing and feeling including consciousness, desire, embarrassment, fear, hunger, joy, pain, personality, pleasure, pride, and rage [1, pp. 10-11]

- Robot: a machine capable of carrying out a complex series of actions automatically; a machine resembling a human being (a humanoid) and able to replicate certain human movements and functions [3]

\subsection{Framing the discussion}

An overview of the general topic of robots and humans is summarized in Table 1. To better inform others a good journalist [4] and Zachman [5] ask basic questions namely, Who?, What?, Where?, When?, Why? and How? Holistic systems thinking descriptors, Big

Table 1: Contexts and questions regarding the general subject of robots and humans-potential implications.

\begin{tabular}{|c|c|c|c|c|c|c|}
\hline $\begin{array}{l}\text { Question } \\
\text { Thinking } \\
\text { Perspective }\end{array}$ & Who? & What? & Where? & When? & Why? & How? \\
\hline Big Picture & $\begin{array}{l}\text { robots and } \\
\text { humans }\end{array}$ & $\begin{array}{l}\text { robots } \\
\text { replacing } \\
\text { humans } \\
\text { to various } \\
\text { degrees }\end{array}$ & $\begin{array}{l}\text { on Earth } \\
\text { primarily }\end{array}$ & $\begin{array}{l}\text { near to far } \\
\text { future }\end{array}$ & $\begin{array}{l}\text { because } \\
\text { robots can } \\
\text { become } \\
\text { much more } \\
\text { capable }\end{array}$ & $\begin{array}{l}\text { by robots be- } \\
\text { coming more } \\
\text { 'intelligent' }\end{array}$ \\
\hline Operational & $\begin{array}{l}\text { several } \\
\text { robotic } \\
\text { and } \\
\text { human } \\
\text { types }\end{array}$ & $\begin{array}{l}\text { robots } \\
\text { mimicking, } \\
\text { challeng- } \\
\text { ing, or } \\
\text { surpassing } \\
\text { human } \\
\text { behavior }\end{array}$ & $\begin{array}{l}\text { any place } \\
\text { not } \\
\text { necessar- } \\
\text { ily } \\
\text { popu- } \\
\text { lated by } \\
\text { humans }\end{array}$ & $\begin{array}{l}\text { present to } \\
\text { far future }\end{array}$ & $\begin{array}{l}\text { to benefit, } \\
\text { replace, or } \\
\text { control } \\
\text { humans }\end{array}$ & $\begin{array}{l}\text { by robots } \\
\text { learning skills, } \\
\text { getting } \\
\text { knowledge, } \\
\text { and 'boot- } \\
\text { strapping' } \\
\text { themselves }\end{array}$ \\
\hline
\end{tabular}


Table 1: (Continued)

\begin{tabular}{|c|c|c|c|c|c|c|}
\hline ive & Who? & What? & Where? & When? & Why? & How? \\
\hline Functional & $\begin{array}{l}\text { special- } \\
\text { ized } \\
\text { robots and } \\
\text { cyborgs }\end{array}$ & $\begin{array}{l}\text { specific } \\
\text { capabili- } \\
\text { ties/ char- } \\
\text { acteristics }\end{array}$ & $\begin{array}{l}\text { physical } \\
\text { areas of } \\
\text { applica- } \\
\text { tion }\end{array}$ & $\begin{array}{l}\text { present to } \\
\text { near future }\end{array}$ & $\begin{array}{l}\text { to empha- } \\
\text { size de- } \\
\text { velopment } \\
\text { aspects }\end{array}$ & $\begin{array}{l}\text { by building } \\
\text { on current } \\
\text { research } \\
\text { efforts and } \\
\text { capabilities }\end{array}$ \\
\hline Structural & $\begin{array}{l}\text { robotic/ } \\
\text { human } \\
\text { body } \\
\text { parts and } \\
\text { intercon- } \\
\text { nections }\end{array}$ & $\begin{array}{l}\text { how parts } \\
\text { work and } \\
\text { are inte- } \\
\text { grated }\end{array}$ & $\begin{array}{l}\text { part } \\
\text { locations } \\
\text { in robots } \\
\text { and } \\
\text { humans }\end{array}$ & $\begin{array}{l}\text { whenever } \\
\text { parts are } \\
\text { active }\end{array}$ & $\begin{array}{l}\text { to learn } \\
\text { how parts } \\
\text { contribute } \\
\text { to func- } \\
\text { tionality } \\
\text { and opera- } \\
\text { tions }\end{array}$ & $\begin{array}{l}\text { by experi- } \\
\text { menting with } \\
\text { parts types and } \\
\text { concepts for } \\
\text { their intercon- } \\
\text { nections }\end{array}$ \\
\hline Generic & $\begin{array}{l}\text { machines } \\
\text { and people }\end{array}$ & $\begin{array}{l}\text { artificial } \\
\text { vs. human } \\
\text { intelli- } \\
\text { gence }\end{array}$ & $\begin{array}{l}\text { wherever } \\
\text { intelli- } \\
\text { gence is } \\
\text { found }\end{array}$ & $\begin{array}{l}\text { whenever } \\
\text { intelli- } \\
\text { gence is } \\
\text { found }\end{array}$ & $\begin{array}{l}\text { to un- } \\
\text { derstand } \\
\text { promise/ } \\
\text { danger of } \\
\text { machine } \\
\text { intelligence }\end{array}$ & $\begin{array}{l}\text { continued re- } \\
\text { search, study, } \\
\text { analysis, } \\
\text { synthesis, and } \\
\text { publication }\end{array}$ \\
\hline Continuum & $\begin{array}{l}\text { continued } \\
\text { evolution } \\
\text { of ma- } \\
\text { chines and } \\
\text { humans }\end{array}$ & $\begin{array}{l}\text { cumulative } \\
\text { collection } \\
\text { of robotic/ } \\
\text { human } \\
\text { properties }\end{array}$ & $\begin{array}{l}\text { any- } \\
\text { where }\end{array}$ & anytime & $\begin{array}{l}\text { to discover } \\
\text { and charac- } \\
\text { terize new/ } \\
\text { important } \\
\text { trends }\end{array}$ & $\begin{array}{l}\text { by maintain- } \\
\text { ing general } \\
\text { and objective } \\
\text { viewpoints }\end{array}$ \\
\hline Temporal & $\begin{array}{l}\text { ages of } \\
\text { robots and } \\
\text { humans }\end{array}$ & $\begin{array}{l}\text { rates of } \\
\text { change in } \\
\text { capabili- } \\
\text { ties }\end{array}$ & $\begin{array}{l}\text { wherever } \\
\text { there is } \\
\text { sig- } \\
\text { nificant } \\
\text { current } \\
\text { focus }\end{array}$ & $\begin{array}{l}\text { whenever } \\
\text { there is } \\
\text { significant } \\
\text { current } \\
\text { focus }\end{array}$ & $\begin{array}{l}\text { to measure } \\
\text { robotic } \\
\text { and human } \\
\text { achieve- } \\
\text { ment } \\
\text { trends }\end{array}$ & $\begin{array}{l}\text { by 'psycho- } \\
\text { logically' and } \\
\text { physically } \\
\text { comparing } \\
\text { robots and } \\
\text { humans }\end{array}$ \\
\hline Quantitative & $\begin{array}{l}\text { relative } \\
\text { popula- } \\
\text { tions of } \\
\text { robots and } \\
\text { humans }\end{array}$ & $\begin{array}{l}\text { distribu- } \\
\text { tion of } \\
\text { robotic } \\
\text { functions }\end{array}$ & $\begin{array}{l}\text { distribu- } \\
\text { tion of } \\
\text { robotic } \\
\text { locations }\end{array}$ & $\begin{array}{l}\text { distribu- } \\
\text { tion of } \\
\text { robotic } \\
\text { timelines }\end{array}$ & $\begin{array}{l}\text { to measure } \\
\text { relative } \\
\text { seriousness } \\
\text { of robotic } \\
\text { activities }\end{array}$ & $\begin{array}{l}\text { by estimat- } \\
\text { ing numbers, } \\
\text { percentages, } \\
\text { and densities }\end{array}$ \\
\hline Scientific & $\begin{array}{l}\text { robotic } \\
\text { research- } \\
\text { ers and } \\
\text { authors }\end{array}$ & $\begin{array}{l}\text { levels of } \\
\text { under- } \\
\text { standing of } \\
\text { robotic } \\
\text { topics }\end{array}$ & $\begin{array}{l}\text { hotbeds } \\
\text { of } \\
\text { robotic } \\
\text { study } \\
\text { and } \\
\text { discourse }\end{array}$ & $\begin{array}{l}\text { years of } \\
\text { robotic } \\
\text { technical } \\
\text { break- } \\
\text { throughs }\end{array}$ & $\begin{array}{l}\text { to get } \\
\text { underpin- } \\
\text { ning of } \\
\text { robotic } \\
\text { engineer- } \\
\text { ing }\end{array}$ & $\begin{array}{l}\text { review of } \\
\text { literature and } \\
\text { potential } \\
\text { personal } \\
\text { interviews }\end{array}$ \\
\hline
\end{tabular}


Picture, Operational, Functional, Structural, Generic, Continuum, Temporal, Quantitative, and Scientific categorize the perspectives taken in attempting to answer any of the questions. [6]

The reader should skim through Table 1 to get a sense of where we are going. In exploring any question/descriptor pair, other questions/descriptors may be invoked.

\subsection{Natural progression of robotic phases}

Suppose there are eight phases in a natural evolutionary progression toward the ultimate sophistication of robots, as depicted in Table 2. Examination and interpretation of this table resonates with many aspects of Table 1 . These phases can be viewed in essentially reverse order timewise of the five propositions posed in the abstract. Specifically, Proposition 1 roughly corresponds to phases VII and VIII, 2 to VI, 3 to V, 4 to IV and 5 to I-III. The five propositions are considered in Section 3, drawing upon research and pronouncements of experts in the field.

The next section expresses thoughts that come to mind to help resolve the propositions. Assume several desired (and perhaps undesired) premises about what robots might eventually accomplish, i.e. the What. Then consider their ramifications by addressing Who, When, Why, Where, and How.

Table 2: Hypothetical evolution of robotic capabilities.

\begin{tabular}{|c|c|c|}
\hline Phase-Era & Label & Brief Description \\
\hline $\begin{array}{l}\text { I-Past and } \\
\text { Present }\end{array}$ & Automation & $\begin{array}{l}\text { What's been going on since at least the times of Henry } \\
\text { Ford and the industrial revolution }\end{array}$ \\
\hline II-Present & $\begin{array}{l}\text { Artificial } \\
\text { Intelligence }\end{array}$ & $\begin{array}{l}\text { Research and experimentation since the mid-20th century, } \\
\text { especially in the past couple of decades }\end{array}$ \\
\hline $\begin{array}{l}\text { III-Present } \\
\text { and Future }\end{array}$ & $\begin{array}{l}\text { Robots Doing } \\
\text { Many Jobs }\end{array}$ & $\begin{array}{l}\text { Robots replacing manual and even white-collar and/or } \\
\text { knowledge-based workers, particularly in the past decade; } \\
\text { many more jobs are threatened }\end{array}$ \\
\hline IV-Very & Big Data & Autocratic psychological influence of many through \\
\hline Near Future & Mind Control & $\begin{array}{l}\text { leveraging huge amounts of automatically collected data plus } \\
\text { some misinformation; is already happening! }\end{array}$ \\
\hline $\begin{array}{l}\text { V-Near to } \\
\text { Far Future }\end{array}$ & $\begin{array}{l}\text { Humans } \\
\text { Turning into } \\
\text { Robots }\end{array}$ & $\begin{array}{l}\text { Seems inevitable as more of us receive artificial body } \\
\text { parts/transplants, including portions of the brain; this is } \\
\text { bound to greatly increase longevity! }\end{array}$ \\
\hline $\begin{array}{l}\text { VI-Far to } \\
\text { Very Far } \\
\text { Future }\end{array}$ & $\begin{array}{l}\text { Robots Doing } \\
\text { All Jobs }\end{array}$ & $\begin{array}{l}\text { Robots doing all the jobs leaving most humans with no } \\
\text { occupational opportunities; the very few elite in control } \\
\text { will own everything, including the robots }\end{array}$ \\
\hline $\begin{array}{l}\text { VII-Very } \\
\text { Far to Distant } \\
\text { Future }\end{array}$ & $\begin{array}{l}\text { Robots } \\
\text { Becoming } \\
\text { Human-Like }\end{array}$ & $\begin{array}{l}\text { AI succeeds in creating robots capable of human } \\
\text { aspirations and qualities like ambition, cognition, } \\
\text { conscience, emotion, faith, learning, memory, morality, } \\
\text { reason, religion, and self-awareness }\end{array}$ \\
\hline $\begin{array}{l}\text { VIII-Very } \\
\text { Distant } \\
\text { Future }\end{array}$ & $\begin{array}{l}\text { Robots } \\
\text { Surpassing } \\
\text { Humans }\end{array}$ & $\begin{array}{l}\text { If/when robots achieve Phase VII, they will quickly and } \\
\text { irreversibly far surpass humanity and potentially } \\
\text { marginalize, minimize, or eliminate us! }\end{array}$ \\
\hline
\end{tabular}




\section{SOME THOUGHTS REGARDING THE FRAMING QUESTIONS}

The basic questions are next addressed in the aforementioned order.

\subsection{What?}

Here posed are a few very long term (see When) outcomes in terms of robotic states; presumably, Premises 1 and 2 below might be desired, and Premise 3 is undesired.

Premise 1 . All jobs are done by robots including making and repairing robots.

If robots do all the jobs, one wonders how anyone would satisfy their innate human aspirations of doing something useful or pleasurable in life. On the other hand, many people would clearly prefer not to be forced to work in undesirable occupations just to make a living, so that can be an upside. Ever since the US was an agrarian society, and transitioned through the industrial and information ages, we've been worried about automation taking over our jobs. The remedies, of course, as has been espoused many times, are proper education and effective retraining so the affected people can aspire to new job opportunities and actually fulfill them successfully with at least adequate expertise. How strongly do these measures still hold?!

Premise 2. Robots miraculously solve many heretofore intractable mysteries and problems posed or exhibited by humans.

Remember the joke about the monkeys and the typewriters, where with enough monkeys randomly typing, and time, one of them would write a brilliant novel? Just think of what could happen with intelligent robots that can collaborate and collectively solve great mysteries and problems such as: a) understanding the beginning of the universe where quantum theory apparently dominates; b) how the human race might maintain or improve our quality of life, even as the climate continually changes, and we continue to deplete the Earth's resources; c) how best to at least combat and mitigate what is becoming very rampant terrorism plaguing the civilized World!; and d) retard the human trend to invent and adopt technologies deleterious to human survival, witness nuclear weapons and automobiles, for example. The robots are more likely to succeed at this premise's endeavors to the extent they work together openly and without, e.g. greed, ignorance, jealousy and rancor, in contrast to what human beings are wont to do. But how do we get robots to behave that way, e.g. with a moralistic conscience and with empathy?

Premise 3. Robots eventually take over completely, similar to what happened in 'The Planet of the Apes' movie [7].

This may be the more far-fetched and rather negative premise, but it resonates somewhat in contemplating if/when we develop a set of processes (without sufficient safeguards) in evolving a strong, but hopefully not dominant, robotic culture.

\subsection{Who?}

Consider that humans are getting new body parts, e.g., hip, knee and shoulder replacements, artificial limbs, and vital organ substitutions, e.g., the heart, liver, lungs, (critical portions of) the brain, etc. Maybe by leveraging those accomplishments with continued improvements in medicine to prolong life over a greater period of time, some human beings will become a lot closer to almost turning into robots. Such an evolution may turn selected members of our species into pseudo-robots that could live essentially forever, depending on the reliability, maintainability, and longevity of the body parts, or at least as long as Methuselah!

This gradual body part replacement scenario may greatly ease the angst about robots doing all the jobs (of Premise 1) while humans atrophy with nothing to do. Also, humanity could become more accepting of the idea of robots, if/when religious beliefs mature further, possibly 
creating momentum to encourage societies to become more atheistic. Other mindsights may gain traction, as well, such as having fewer babies to help the overpopulation problem, and demanding fewer material goods, both of which would slow the depletion of the Earth's resources and mitigate what is likely to be a continual decrease in our quality of life.

\subsection{When?}

It seems rather obvious that none of the premises posed, at least so far, have much chance of being realized within mere decades. And it is impossible to accurately predict when any of the premises might be realized. Even if we are fortunate enough to suggest some feasible ways forward, we should not expect to pre-specify outcomes or anticipate any timelines for progress. This is the nature of any truly complex system. One can try to influence the system but should be content to observe what happens and patiently await trends of the system's evolution before bravely intervening again.

\subsection{Why?}

Regarding Premise 1, we already know of debate among some economists asking:

a. What would this do to economies and people?

b. How would people survive?

c. Would people have to earn a living/make money if all labor, food production, teaching, etc., is done essentially for free? If so, how?

d. Would we end up with a largely 'flat society' of plenty, or something much more sinister (see e and h below)?

e. Will we become an oligarchy with only a few 'families' owning everything?

This premise is a very complex thing to fathom.

Not to mention what would happen to marriage and human reproduction if some robots became almost indistinguishable from humans and could have sex.

f. Would many people still choose to have a human spouse over the perfect robot, made or used as a substitute for an imperfect human partner?

g. But what if some people become more robotic with advances in medicine so that they transform into superior beings, and what would they do then?

h. What if they or the robots surpass humans and ultimately take over?

\subsection{Where?}

We might consider establishing an experimental environment for testing the idea of robots being pervasively integrated into our societies where the laboratory is made extraterrestrial, either on the moon, another planet like Mars, or even within an artificially created earthlike structure which orbits the Earth. One would have to be assured, at least initially, that the robots could not escape this environment and come to Earth before we have developed these premises sufficiently to assure our safety.

Yampolskiy devotes a chapter in his excellent book [8, pp. 145-165] to the AI 'confinement' problem because of its grave dangers, a theme he is quite convincing in espousing, e.g. '... (AGI) research should be considered unethical.' [8, p. 139] 


\subsection{How?}

Considering Premise 1, in one case governments could make the robots, and they would be essentially free. Various questions arise.

a. Then would we just abolish money and have anything we want?

b. What would that scenario look like?

In another case, a few people might own the robot companies privately.

c. If no one works, then who buys the robots?

d. Or how would they be allotted and to whom?

Under any of the premises, we should consider and think about what could go wrong. People hungry for power might be able to corrupt the system so that they could control the robots, and thereby everyone else as well.

e. What kind of safeguards could be put in place?

f. In developing a robotic mind, is it even possible to be assured robotic minds will have only benevolent motives and will not turn against the human race?

g. Even given that, how do we know what to expect robotic behaviors to be?

We would need a pretty comprehensive set of failsafe mechanisms.

Optimistically speaking there are continual technological breakthroughs which help researchers explore how the mind works. [9] With such concerted efforts over long periods of time (see When above) it might well be possible to develop robotic minds to be not only smart and creative but also benevolent.

\section{PROPOSITIONS}

Consider the foregoing as background, primarily. We now come to the main section of this paper where the five propositions are discussed. Liberal use of quotations (using '...'s) from other authors is employed to show various points of view. This author will agree/disagree to certain extents and provide his overall assessments.

\subsection{Proposition 1: Could robots become human or even surpass humans?}

Will AI efforts in robotics eventually achieve a state where robots possess human-like capabilities of cognition, emotion, learning, etc.? If so, then it may become inevitable that robots would greatly accelerate their capabilities with their own self-learning while leaving humans behind. So much so that there would be grave dangers that the human race will become marginalized, at best, or annihilated, at worst.

- '[I] warn you that artificial intelligence could drive mankind into extinction, and [I'll] explain how that catastrophic outcome is not just possible, but likely if we do not begin preparing very carefully now. ... consider this [an] invitation to join the most important conversation [we] can have.' [2, p. 16]

- '... AI could [achieve and surpass] human intelligence through the process of recursive self-improvement powers including self-replication, swarming a problem with many versions of itself, super high-speed calculations, running 24/7, mimicking friendliness, playing dead and more. We've proposed that an [ASI] won't be satisfied with remaining 
isolated; its drives and intelligence would ... put our existence at risk.' [2, p. 70]

- '[Alan] Turing's wartime assistant, mathematician I. J. Good, suggested that the last invention human beings need to create is the first ultra-intelligent machine. ... Don't panic, though: I can't see that we're any closer to achieving it than we were 50 years ago.' [10, p. 87]

- '... the first ultraintelligent machine is the last invention that man need ever make, provided that the machine is docile enough to tell us how to keep it under control ...' [2, p. 105]

- '[but] ... a real artificial intelligence would be smart enough to not reveal itself.' [10, p. 90]

- '... the human brain actually uses many of the same computation techniques as computers. But ... it's not clear if computers will think as we define it, ... Therefore, some scholars say, artificial intelligence equivalent to human intelligence is impossible.' [2, p. 45]

- 'Our survival, if it is possible, may depend on, among other things, developing AGI with something akin to consciousness and human understanding, even friendliness, built in.' [2, p. 46]

- 'In contrast with our intellect, computers double their performance every eighteen months. So the danger is real that they could develop intelligence and take over the world.- Stephen Hawking, physicist.' [2, p. 148]

Despite Hawking's genius and being one of this author's all-time heroes, there's something missing here! How can a machine become 'intelligent' by just continuing the 'brute force' approach of Moore's Law?! Machines can't evolve as human's have done unless they somehow get intelligence (that special thing that must be there to achieve the ultimate change to ASI). This roadblock seems analogous to Turing's halting problem and Gödel's incompleteness theorem. There are true things within our civilization that we (in our civilization) cannot prove, e.g. the statements that machines/robots can - or can never - become intelligent!

Yampolskiy [8] elegantly warns of the ASI dangers. He feels it is quite possibly achievable and has suggested various methods of protecting against it.

- '... Unfortunately, the majority of AI books on the market today talk only about what AI systems will be able to do for us, not to us. I think that this book, which in scientific terms addresses the potential dangers of AI and what we can do about such dangers, is extremely beneficial to the reduction of risk posed by artificial general intelligence (AGI).' [8, p. 184]

- 'Kurzweil isn't concerned about roadblocks to AGI since his preferred route is to reverse engineer the brain. He believes there's nothing about brains, and even consciousness, that cannot be computed. [The theory of computation disputes this though!] In fact, every expert I've spoken with believes that intelligence is computable.' [2, p. 163]

- ' $\ldots$ an intelligence explosion may be unavoidable once almost any AGI system is achieved. When any system becomes self-aware and self-improving [but could it?!], its basic drives, ... virtually guarantee that it will seek to improve itself again and again.' [2, p. 163]

- 'If AI researchers do eventually manage to make the leap to AGI, ... the result will [not "just"] be a machine that simply matches human-level intelligence. ... such a system would eventually ... focus its efforts on improving its own design, rewriting its software, or perhaps using evolutionary programming techniques to create, test and optimize enhancements to its design. ... an iterative process of "recursive improvement." ... the ultimate result would be an "intelligence explosion" - quite possibly culminating in a machine thousands or even millions of times smarter than any human being. As Hawking and his collaborators put it, it "would be the biggest event in human history."” [11, pp. 232-233]

- ' $\ldots$ the invention of [ASI] - [may be] ultimately prove[en] [There is no way of proving this or the alternative.] impossible or will be achieved only in the very remote future. A 
number of top researchers with expertise in brain science have expressed this view. Noam Chomsky ... says we're "eons away" from building human-level machine intelligence, and that the Singularity [ASI] is "science fiction." Harvard psychologist Steven Pinker agrees, saying, "There is not the slightest reason to believe in a coming singularity. The fact that you can visualize a future in your imagination is not evidence that it is likely or even possible."' [11, pp. 236-237]

This author sides with Chomsky's and Pinker's expert opinions, though not declaring impossibility, but believing that any possibility for this sort of outcome is many eons away, depending mainly on the further evolution of humans and/or robots. A good sense of this can be acquired by reading Pinker [12] and Dawkins [13], for example.

- '... the problem of AGI is simply too difficult for humans, no matter how long we chip away at it. ... we may not possess minds that can understand our own minds. ... it might require intelligence greater than our own to fathom our intelligence in full.' [2, pp. 163-164]

- '.. we will never achieve AGI ... because of the problem of creating human-level intelligence will turn out to be too hard. ...' [2, p. 189]

This author tends to believe this quotation, and other similar opinions, so his answer to Proposition 1 is 'No.' The reader is invited to consider the above quotations, delve into further remarks in the cited references, and make up their own mind.

Deterministic software can result in unpredictable behaviors that are unforeseen, i.e. emergent, and even surprising. But that's not the same as creating an AGI being.

Despite remarkable advances in voice recognition and natural language processing, languages are still imprecise and open to interpretation; we often cannot agree on definitions but we can exchange our perceptions of the underlying reality (which no one can truly grasp by themselves) to understand each other better and get a better idea of reality collectively. And partly because of this we cannot instruct a robot on how to become 'intelligent' either!

Maybe our best defense against the dangers of ASI would be in improving our understanding of why even AGI (and thereby ASI) can 'never' be achieved, at least not faster than the prospect of improved humans through further eons of evolution!

\subsection{Proposition 2: What if robots take over all the jobs?}

Maybe robots will never surpass us or become truly human but what if they become so adept and pervasive that they eventually take over all our jobs!?

Even at the accelerated rate robotic applications are heading in this direction, it would likely take a very much longer for us to lose all our jobs. Not that this would be so bad for many who crave more leisure time.

Figure 1 pictorially describes what could be the ultimate reality where robots do all the jobs including the fabrication/maintenance/repair/disposition of robots. Robots perform labor for everyone including the owners of the robots and the government. The owners may include government personnel, and if there are no taxes, the owners would support government directly. The owners possess all wealth, which includes all natural and artificial resources, land and material goods resulting from the means for production and jobs. Robots utilize resources which belong to the few owners of all the robots. Robots provide military protection to everyone, including the government which leads that capability. Of course, 


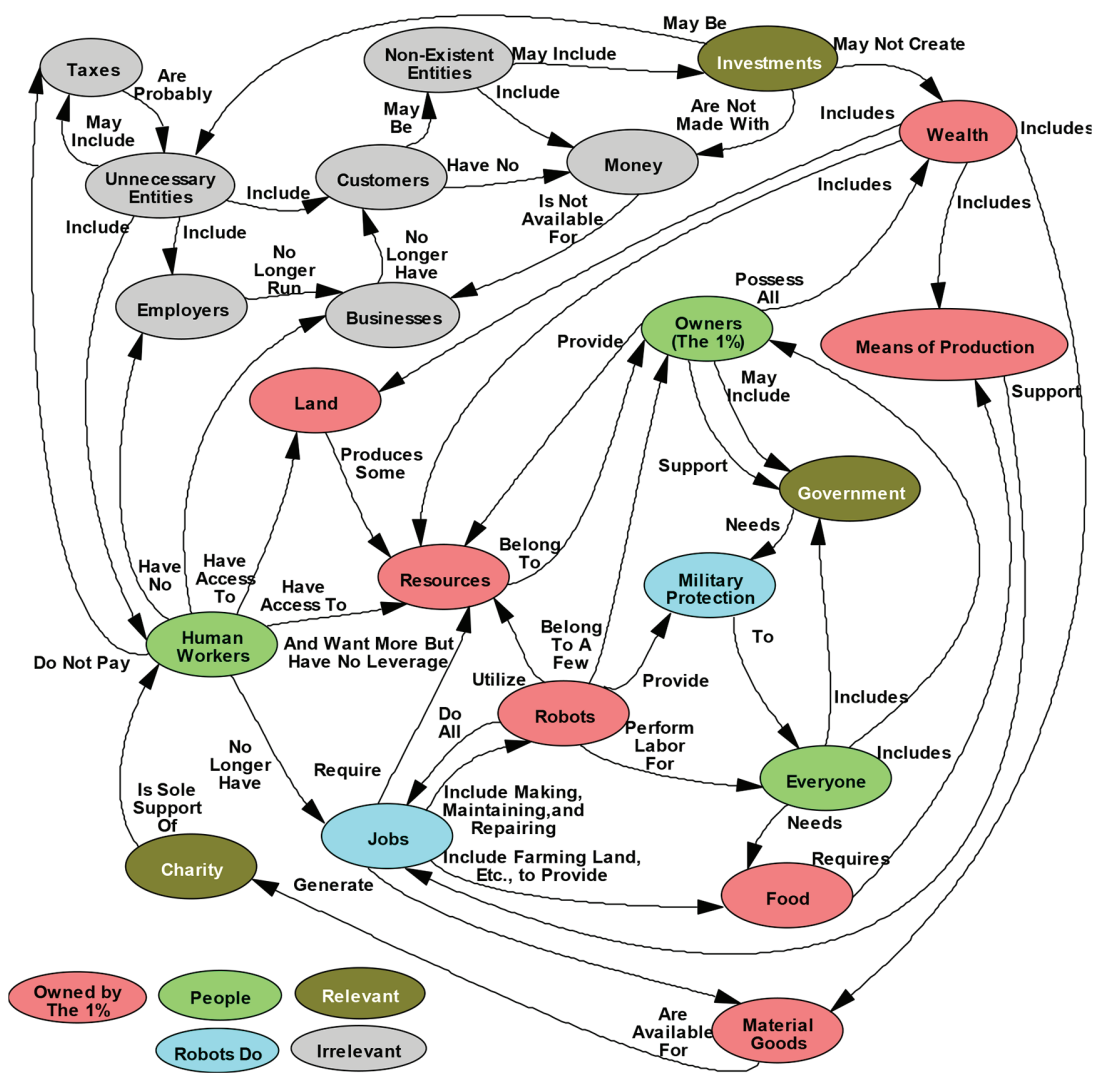

Figure 1: Ultimate reality when robots perform all jobs.

everyone eats food which becomes available through jobs the robots perform using all means for production. Thus, the previously viable human workers no longer have jobs or access to resources. Although they no longer pay taxes and have no employers, these humans do still have access to businesses and land. Humans, as former workers, are solely supported by charity which is derived from material goods and services produced by robots now doing all their jobs. Businesses no longer have customers, who in turn have no money, so businesses cannot prosper and employers cannot run them. Since money does not exist, investments might be made in other ways but still may not create wealth. Unnecessary entities include employers' customers as well as human workers, although customers may also be nonexistent. Taxes are also probably unnecessary.

- 'People don't seem to mind when robots clean their floors, build their cars, administer their medication, or perform their surgery. These examples, however, are all agencyrelated examples of thinking and doing; there seems to be something very different about a robot that can sense and feel. In robots we seem to be hesitant to combine agency with experience, to make a human machine.' [1, p. 73]

- 'I am profoundly grateful to parents for raising the generation who will be programming the robot to look after me in my decrepitude, ...' [10, p. 204] 
Personal healthcare is one area where robots may take longer to replace human caregivers because of the ability of humans to show genuine empathy and emotional support to patients, particularly those with dementia, Alzheimer's disease, etc.

Ultimately, there would be a very small minority of humans that literally own everything, including all the robots. These extremely elite owners would be expected to subsidize the rest of humanity to ensure others' existence at some reasonable levels, or even peoples' survival - or not! What is to prevent these owners from remaining selfish and evilly shirking their moral duty?!

\subsection{Proposition 3: Will humans essentially turn into pseudo-robots?}

Considering the [im]possibility of robots becoming human or more, as discussed under Proposition 1, what about humans becoming more robot-like? Wouldn't that proposition a lot easier to achieve?

The key to this might be the extent to which medicine advances mimicking portions of the human brain, perhaps sub-human in capability but good enough for robotic behavior. The more challenging aspects of the brain, that just cannot be copied, as yet, would remain human. Voila!, a pseudo-robot (or cyborg, for cybernetic organism [14]) that is still somewhat (mostly?) human.

- 'What exactly will constitute a "robot" when humans augment their bodies and brains with intelligent prosthetics and implants?' [2, p. 21] [One concern: how would efficient power be provided to the artificial parts while the metabolism and muscles of the human portion shrink?]

- '... detrimental effects come from computers outside our bodies. Yet Kurzweil proposes only good things will come of computers inside our bodies. I think it's implausible to expect that hundreds of thousands of years of evolution will turn on a dime in thirty years, and that we can be reprogrammed ...' [2, p. 147]

- 'Homo sapiens are not known to be particularly harmless when in contact with one another, other animals, or the environment. Who is convinced that humans outfitted with brain augmentation will turn out to be friendlier and more benevolent than machine[s] [with ASI]? ...' [2, pp. 156-157]

It seems quite doubtful that medical and other researchers will ever be able to produce even a partially synthetic brain that guarantees benevolence. Indeed, how does one define such agreeable, caring, and harm-avoiding behavior when any set of postulated 'laws' would likely be at least somewhat ambiguous and not 'air tight?'

\subsection{Proposition 4: Will Big Data Authoritarians Psychologically Control Us?}

Someday, someone quite autocratic might be able to capture power through a populist vote of the disenchanted who want change. S/he would probably be adept at spreading falsehoods without offering facts, and over a rather short period of time bolster support among her/his populace and hoodwink others. From there it's a relatively easy step to leverage Big Data in achieving '1984' - like control of public thought. [15] In 2012 former US Supreme Court Justice David Souter gave us a somber warning. [16] Here are excerpts.

- ‘... "an ignorant people can never remain a free people." Democracy cannot survive too much ignorance ... [Benjamin] Franklin was asked by someone ... what kind of 
government the constitution would give us if it was adopted. Franklin's famous answer was "a republic, if you can keep it." You can't keep it in ignorance. ... What I worry about is that when problems are not addressed, people will not know who is responsible. And when the problems get bad enough, ... some one person will come forward and say, "Give me total power and I will solve this problem."

- 'Privacy includes our right to keep a domain around us, which includes ... our body, home, property, thoughts, feelings, associations, secrets and identity. The right to privacy gives us the ability to choose which parts in this domain can be accessed by others, and to control the extent, manner and timing of the use of those parts we choose to disclose.' [10, pp. 236-237]

- '... privacy [is divided] into three equally [important] parts: 1) Secrecy—our ability to keep our opinions known only to those we intend to receive them, ... 2) Anonymity secrecy about who is sending and receiving an opinion or message, and 3) Autonomy ability to make our own life decisions free from any force that has violated our secrecy or anonymity. Without privacy, nobody can be fully autonomous or free.' [10, p. 237]

\subsection{Proposition 5: Will humans keep losing many more jobs to robots?}

Despite the addition of millions of jobs in the US under President Obama and a quite low unemployment rate of about $4.7 \%$ (as of 9 March 2017), the percentages of those with just part-time jobs is about $9 \%$ (though dropping), and those not even looking for work is roughly $12 \%-15 \%$. The latter two statistics are significantly impacted by automation and robots taking over manual and some white-collar and/or knowledge-based jobs. It should be recognized that this trend will likely continue.

- '... the first decade of the twenty-first century resulted in the creation of no new jobs. Zero. ... [This] is especially astonishing when you consider that the US economy needs to create roughly a million jobs per year just to keep up with growth in the size of the workforce.' [11, p. xi] [A mitigating factor might develop if we started having significantly fewer babies! [17]]

- '... a great many jobs and tasks are likely to be encapsulated in [Big Data] waiting for the day when a smart machine learning algorithm comes along ... As an example, consider radiologists, ... computers are rapidly getting better at analyzing [very large numbers of very complicated] images. It's quite easy to imagine that someday, in the not too distant future, radiology will be a job performed almost exclusively by machines. ... Indeed, ... employment for many skilled professionals-including lawyers, journalists, scientists, and pharmacists—is already being significantly eroded by [AI]. ... most jobs are, on some level, fundamentally routine and predictable, with relatively few people paid primarily to engage in truly creative work or "blue-sky" thinking.' [11, pp. $\mathrm{xV}-\mathrm{i}]$

- '... one of the most fundamental ideas woven into the American ethos-the belief that anyone can get ahead through hard work and perseverance-really has little basis in statistical reality.' [11, p. 47]

- 'The hollowed-out middle of the already polarized job market is likely to expand as robots and self-service technologies eat away at low-wage jobs, while increasingly intelligent algorithms threaten higher-skill occupations. ... occupations amounting to nearly half of US total employment may be vulnerable to automation within roughly the next two decades. 
... If, as seems likely, advancing technology continues to drive the [US] and other industrialized countries toward ever higher inequality, then the political influence wielded by the financial elite can only increase.' [11, p. 59]

This will become quite telling and tragic for those who voted for Donald Trump in 2016, thinking he will be able to bring back their old jobs or create new jobs. Their job losses are not due to some group of politicians!

- 'The evaporation of thousands of skilled information technology jobs is likely a precursor for a much more wide-ranging impact on knowledge-based employment. ... software will be hosted in the cloud. ... [and software] will eventually be poised to invade virtually every workplace and swallow up nearly any white-collar job that involves sitting in front of a computer manipulating information.' [11, p. 107]

- '... offshoring is very often a precursor of automation, and the jobs it creates in low-wage nations may prove to be short-lived as technology advances. What's more, advances in artificial intelligence may make it even easier to offshore jobs that can't yet be fully automated.' [11, p. 115]

Here's an idea. Maybe tap the wealthy (highly successful) entrepreneurs to share most of their accumulated and future wealth with the general public to help the lower (and even middle) classes survive economically. This would, in part, be payback for some of the public's earlier tax revenue which fueled many innovators with Federal research grants through DARPA (Defense Applied Research Project Agency), NSF (National Science Foundation), universities, small businesses, etc. [11, pp. 80-81]

- 'For progressives, a guaranteed income may be an easier sell in the current political environment. Despite [the conservative market-based approach] argument to the contrary, many liberals would likely embrace the idea as a method to achieve more social and economic justice. A basic income could effectively ... alleviate poverty and mitigate income inequality. At a stroke of the presidential pen [unlikely to happen under Trump's Republican-controlled Congress, of course], extreme poverty and homelessness in the United States might effectively be eradicated.' [11, pp. 259-261]

- 'I don't see anything especially dystopian in offering some relatively unproductive people a minimal income as an incentive to leave the workforce, as long as the result is more opportunity and higher incomes for those who do want to work hard and advance either situation.' [11, p. 269]

- 'Instead, we ought to transition [toward less labor and more capital] taxation that asks more from those businesses that rely heavily on technology and employ relatively few workers.' [11, pp. 277-278] [Let's also do better in retraining threatened workforces and educating our young.]

- 'The widely held belief that a degree in engineering or computer science guarantees a job is largely a myth. An April 2013 analysis by the Economic Policy Institute found that at colleges in the United States, the number of new graduates with engineering and computer science degrees exceeds the number of graduates who actually find jobs in these fields by 50 percent.' [11, p. 127] [Online education is a possible answer if the current gap in the ability of employers to be assured that online participants have really learned something useful to their businesses can be narrowed. [18]] 
- 'Unemployment is going to be a serious problem - but not, surprisingly, because of a lack of jobs. Rather, the skills required to do the available jobs are likely to evolve more quickly than workers can adapt without significant changes to how we train our workforce.' [19, p. 13] [Maybe we need Proposition 2 to become a reality!]

\section{CONCLUSION}

The propositions posed are important to contemplate but are by no means settled. Many authors familiar with artificial intelligence (AI) and the subject of robots have expressed their judgments, as indicated by many of the quotations provided here. After perusing much of the literature on the subject, this author believes

- Humans will never be able to produce human or super-human intelligent robots. This could only happen through natural evolution over eons; if it does there would definitely be an end to human life as we know it.

- Theoretically robots could take over nearly all the jobs performed by humans if present trends continue indefinitely. This could be the ultimate widening of the income gap between the wealthy $1 \%$ and the rest of us.

- A modicum of humans will eventually become pseudo-robotic through artificial body-part replacements as medical knowledge and effective practice in this direction continues to blossom.

- Big data techniques will increasingly be leveraged by dictators, autocrats and/or their proponents and pretenders to stultify learning and factual knowledge among the masses for the purposes of psychological control.

- Job losses among human workers will accelerate in favor of robots. An increasing awareness that our methods of education and retraining require revolutionary transformations is necessary to alleviate these effects.

\section{ACKNOWLEDGMENTS}

Beaumont Vance posed the question of Proposition 2 which stimulated the author to develop this paper. Thanks to Wayne Davis for several astute comments, and to Matthew Joordens for his interest in collaborating, and a definition of cyborg.

\section{REFERENCES}

[1] Wegner, D.M. \& Gray K., The Mind Club-Who Thinks, What Feels, and Why It Matters, Viking: New York, 2016. [a largely psychological treatment of how we perceive 'mind']

[2] Barrat, J., Our Final Invention-Artificial Intelligence and the End of the Human Era, St. Martins Press: New York, 2013. [a pretty scary treatise!]

[3] The Oxford American College Dictionary, Putnam: New York, 2002.

[4] Huang, T., 6 questions that can help journalists find a focus, tell better stories. Poynter, 9 May 2011, available at http://www.poynter.org/2011/6-questions-that-can-helpjournalists-find-a-focus-tell-better-stories/131491/

[5] Zachman, J.A., The Zachman Framework for Enterprise Architecture, Zachman Institute for Framework Advancement (ZIFA), available at www.zifa.com

[6] Kasser, J. \& Mackley, T., Applying systems thinking and aligning it to systems engineering. 18th INCOSE International Symposium, Utrecht, Holland, 2008. 
[7] "Planet of the Apes," Movie, Director: Franklin J. Schaffner, Writers: Michael Wilson (screenplay), Rod Serling (screenplay), Stars: Charlton Heston, Roddy McDowall, Kim Hunter, 3 April 1968, available at: http://www.imdb.com/title/tt0063442/

[8] Yampolskiy, R.V., Artificial Superintelligence-A Futuristic Approach, CRC Press: Boca Raton, 2016. [very "theory of computation" oriented]

[9] Joseph, A., Lighting the way in brain science. The Boston Globe, 12 November 2015, p. C5.

[10] Harkness, T., Big Data-Does Size Matter? Bloomsbury Sigma: London, 2016. [good account of what is known about us, individually and collectively]

[11] Ford, M., The Rise of Robots-Technology and the Threat of a Jobless Future, Basic Books: New York, 2015. [how computers and automation are taking over even knowledge-based jobs]

[12] Pinker, S., How the Mind Works, W. W. Norton \& Company: New York, 2009. [advocates the credibility of evolution]

[13] Dawkins, R., The Selfish Gene, 30th Anniversary edition, Oxford University Press: Oxford, 2006. [includes a treatment of evolution]

[14] Cyborg, Wikipedia, the free encyclopedia, available at https://en.wikipedia.org/wiki/ Cyborg.

[15] Orwell, G., 1984 - a novel, Secker and Warburg: London, 1949.

[16] available at http://crooksandliars.com/2016/10/justice-david-souter-civic-ignorance-how.

[17] White, B.E., Applying complex systems engineering in balancing our earth's population and natural resources. The 7th International Conference for Systems Engineering of the Israeli Society for Systems Engineering (INCOSE_IL), Herzlia, Israel, 4-5 March 2013. [suggests incentives for having fewer babies]

[18] White, B.E. \& Gandhi, S.J., The Case for Online College Education-a work in progress, American Society for Engineering Education (ASEE) Annual Conference, Atlanta, GA, 23-26 June 2013. [promising alternative to having to go but not affording college]

[19] Kaplan, J., Humans Need Not Apply-A Guide to Wealth and Work in the Age of Artificial Intelligence, Yale University Press: New Haven, 2015. [on how many common jobs are threatened by artificial intelligence, and related questions of morality, human rights, and income/wealth inequality] 